\begin{tabular}{|c|c|c|}
\hline & Int.J.Curr.Microbiol.App.Sci (2016) 5(10): 10-15 & \multirow{2}{*}{ 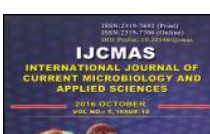 } \\
\hline & \multirow{4}{*}{$\begin{array}{l}\text { International Journal of Current Microbiology and Applied Sciences } \\
\text { ISSN: 2319-7706 Volume } 5 \text { Number } \mathbf{1 0}(\mathbf{2 0 1 6 )} \text { pp. 10-15 } \\
\text { Journal homepage: http://www.ijcmas.com }\end{array}$} & \\
\hline & & \\
\hline EXCELLENT & & \\
\hline PUBLISHERS & & wwwijijemas com \\
\hline
\end{tabular}

Original Research Article

http://dx.doi.org/10.20546/ijcmas.2016.510.002

\title{
Serologic Study on Leptospirosis Infection in Cattle in Main Albanian Coastline Districts
}

\author{
Luljeta Alla $^{1}$, Rushdi Keçi ${ }^{2}$ and Xhelil Koleci ${ }^{2} *$ \\ ${ }^{1}$ Institute of Public Health, Department of Control of Infection Diseases, Albania \\ ${ }^{2}$ Faculty of Veterinary Medicine, Agricultural University of Tirana, Albania \\ *Corresponding author
}

\begin{abstract}
A B S T R A C T
Keywords

Seroprevalence, Leptospirosis,

Albania,

Micro-

agglutination test

(MAT)

Cattle.

\section{Article Info}

Accepted:

12 September 2016

Available Online:

10 October 2016

In this study we tested 550 sera blood samples in order to investigate seroprevalence of leptospiral infection in cattle managed in coastline area from Shkodër to Vlora in Albania. The sera samples were tested by means of the microagglutination test (MAT). Sera were stored at $-20^{\circ} \mathrm{C}$ until use. They were initially screened at serum dilution of 1:100 against 9 strains of pathogenic serovars of Leptospira: icterohaemorrhagiae, canicola, copenhageni, pomona, hardjo, bratislava, tarassovi, grippotyphosa and ballum. The samples were judged as positive if $\geq 50 \%$ of agglutination of leptospira in a dilution test serum of $\geq 1: 100$ were observed. Sera with positive results were titrated against reacting antigens in serial two-fold dilutions from 1:100 to 1:3200. Antibodies against one or more serovars were detected in $65(11.9 \%)$ sera at dilution $\geq 1: 100$. Antibodies against more than one serovar were found in $5(0.9 \%)$ positive sera. Among the positive sera, antibodies were most frequent to serovar Icterohaemorrhagiae 36.9\%, Hardjo $30.8 \%$, Grippotyphosa $16.9 \%$, Pomona $9.2 \%$, Copenhageni $3.1 \%$, Bratislava $3.1 \%$. The results of this survey indicate that leptospiral infection is common in dairy cattle.
\end{abstract}

\section{Introduction}

Leptospirosis is bacterial infection disease that affects all farm animal species and human. It is a re-emergent global zoonotic disease (Bharti et al., 2003). The genus Leptospira is quite diverse and to date there are known 17 genospecies. Based on serological methods there are identified more than 250 serovars. Many serovars are adapted in specific hosts, while animals and humans may be affecting by several serovars.
Both direct and indirect transmissions are well described. A range of hosts, such as wildlife animals, pigs, horses cattle and rats are identified as main and or alternative reservoirs for pathogenic leptospires in animals. Clinical signs in infected cattle vary from subclinical to severe disease. There are described milk drop syndrome, abortions, hemoglobinuria, jaundice, fever, and rarely meningitis. Most commonly serovars involved in cattle are, $L$. Pomona, $L$. 
Grippotyphosa, L. Icterohaemorrhagiae (Prescott et al., 1988; Mughini-Gras et al., 2014; Garvey et al., 2014).

The epidemiology and diagnosis of infection with leptospires by isolation of pathogen is difficult and problematic (Lilenbaum and Martins, 2014). In many countries, diagnostic laboratories do not attempt to isolate leptospires because of their fragile nature, cost and complexity of the isolation method, and long incubation period. Serological methods are extensively used in both human and veterinary medicine (Wynwood et al., 2016). Despite there are described and used a range of serological tests, two tests are more commonly applied in veterinary diagnosis, 1) the microscopic agglutination test (MAT) and 2) enzymelinked immunosorbent assay (ELISA) (Cumberland et al., 1988 (OIE, 2014).

In Albania, the cattle livestock sector represents an important part of the household economy. The cattle management is based on traditional system where cograzing with other species is a common practice. The prevalence and circulation of Leptospira serovar Hardjo, for which bovine represents the maintain host, as well as the occurrence of infections caused by other pathogenic serovars of Leptospira are not well documented, although typical clinical signs indicate presence of infection. Furthermore, several human cases of leptospirosis are reported in Albania, involving cattle as recognised source of infection.

The aim of the study was the evaluation of the leptospirosis seroprevalence in Albanian cattle population. The serum samples were tested by means of the microagglutination test (MAT) using a panel of 9 strains of pathogenic serovars of Leptospira: icterohaemorrhagiae, Canicola,
Copenhageni, Pomona, Hardjo, Bratislava, Tarassovi, Grippotyphosa and Ballum. The sera screening dilution was 1: 100, then twofold serial dilution were prepared to obtain the titre.

\section{Materials and Methods}

In total we tested 550 bovine sera blood samples taken from cattle managed in four districts, 15 villages and 220 farms located on Albania coastline. The samples were tested at accredited laboratory of Istituto Zooprofilattico Sperimentale delle Venezie, Legnaro (PD), Italy.

The serum samples were tested by means of the microagglutination test (MAT) using a panel of 9 strains of pathogenic serovars of Leptospira: Icterohaemorrhagiae, Canicola, Copenhageni, Pomona, Hardjo, Bratislava, Tarassovi, Grippotyphosa and Ballum. The sera screening dilution was 1:100, then twofold serial dilution were prepared to obtain the titre.

\section{Results and Discussion}

The MAT results are presented on Table 13.

The overall sero-prevalence found was 11, $9 \%$; the leptospira antibodies for at list one serovar were found in four districts $(100 \%)$, 10 of 11 villages $(91 \%)$ and $50(22.7 \%)$ of 220 herds (Table 1 ).

Distribution of leptospiral infection in cattle in various districts was significantly different (Table 3).

The highest positive herds were in found in Durrës $40 \%$, and lowest was in Lezha $(15.3 \%)$, whereas in Shkodër was 16.9\% and Vlora 20.7\% (Figure 1). 
The reported results of seroprevalence of leptospiral infection in cattle are different from country to country.

These differences may be the consequence of environmental factors and control efforts. The environmental factors have been shown to have influential effects on development of leptospiral infection in animal and human beings. Long-term survival of pathogenic leptospires outside the host requires a warm, moist environment with a near neutral $\mathrm{pH}$ (Miller et al., 1991).

Out of 9 serotypes there were detected specific antibodies to six leptospira serovars. Antibodies were most frequent to serovar Icterohaemorrhagiae 36.9\%, Hardjo 30.8\%, Grippotyphosa 16.9\%, Pomona 9.2\%, Copenhageni 3.1\%, Bratislava 3.1\% (Table 2).
The majority of titer levels were 1:100 for all serovars and the frequency of 1:100, $1: 200,1: 400$ and $1: 800,1: 1600$ and $1: 3200$ were $67.7,4.6,9.2,10,7,6.2$ and $1.5 \%$, respectively.

Considering the cut-off 1:400, suggestive of acute infection, only $27.7 \%$ of samples showed the significant titres. Antibodies to $L$. Icteroha-emorrhagiae were at low titers, at cutoff level 1:100, and only one sample was at 1:400 titer (Table 2).

All positive samples for $L$. Copenhageni were at 1:100 titers. The antibody titers for $L$. Pomona, for which cattle serve as main and alternative reservoirs of infection, was quite diverse and $50 \%$ of them were at 1:400 and 1:800, even for $16.7 \%$ the titer was as highest 1:3200 (Table 2, and Figure 2).

Table.1 The serological evidence of leptospirosis infection based on MAT results according, districts and villages at farms level

\begin{tabular}{|l|c|c|c|c|}
\hline \multicolumn{1}{|c|}{ Districts } & $\begin{array}{c}\text { No of tested } \\
\text { farms }\end{array}$ & Positive farms & $\begin{array}{c}\text { Negative } \\
\text { farms }\end{array}$ & $\begin{array}{c}\text { Positive } \\
\text { percentage }\end{array}$ \\
\hline Durrës & $\mathbf{5 5}$ & $\mathbf{2 2}$ & $\mathbf{3 3}$ & $\mathbf{4 0}$ \\
\hline Lagjia 15 & 31 & 15 & 16 & 48.4 \\
\hline Ramilli & 1 & 1 & 0 & 100 \\
\hline Sukth & 23 & 6 & 17 & 26.1 \\
\hline Lezhë & $\mathbf{5 9}$ & $\mathbf{9}$ & $\mathbf{5 0}$ & $\mathbf{1 5 . 3}$ \\
\hline Gjadër & 15 & 2 & 13 & 13.3 \\
\hline Gocaj & 5 & 2 & 3 & 40 \\
\hline Tale & 39 & 5 & 34 & 12.8 \\
\hline Shkodër & $\mathbf{7 7}$ & $\mathbf{1 3}$ & $\mathbf{6 4}$ & $\mathbf{1 6 . 9}$ \\
\hline Bërdice e Madhe & 24 & 6 & 18 & 25 \\
\hline Dheu i Lehtë & 26 & 5 & 21 & 19.2 \\
\hline Shelqet & 17 & 2 & 15 & 11.8 \\
\hline Vlorë & $\mathbf{2 9}$ & $\mathbf{6}$ & $\mathbf{2 3}$ & $\mathbf{2 0 . 7}$ \\
\hline Nartë & 24 & 6 & 18 & 25 \\
\hline Shkozë & 5 & 0 & 5 & 0 \\
\hline \multicolumn{1}{|c|}{ Total } & $\mathbf{2 2 0}$ & $\mathbf{5 0}$ & $\mathbf{1 7 0}$ & $\mathbf{2 2 . 7}$ \\
\hline
\end{tabular}


Table.2 Distribution of serovar specific anti-leptospirosis antibodies and their titration in seropositive samples.

\begin{tabular}{|l|l|c|c|c|c|c|c|}
\hline $\begin{array}{l}\text { Serovarsltiters of } \\
\text { Leptospires }\end{array}$ & $\mathbf{1 : 1 0 0}$ & $\mathbf{1 : 2 0 0}$ & $\mathbf{1 : 4 0 0}$ & $\mathbf{1 : 8 0 0}$ & $\mathbf{1 : 1 6 0 0}$ & $\mathbf{1 : 3 2 0 0}$ & Total \\
\hline Icterohaemorrhagiae & $23(95.8)$ & & $1(4.2)$ & & & & $\mathbf{2 4}(36.9)$ \\
\hline Copenhageni & $2(100)$ & & & & & & $\mathbf{2}(3.1)$ \\
\hline Pomona & $2(33.3)$ & & $1(16.7)$ & $2(33.3)$ & & $1(16.7)$ & $\mathbf{6}(9.2)$ \\
\hline Hardjo & $8(40)$ & $2(10)$ & $3(15)$ & $4(20)$ & $3(15)$ & & $\mathbf{2 0}(31.1)$ \\
\hline Bratislava & $1(50)$ & $1(50)$ & & & & & $\mathbf{2}(3.1)$ \\
\hline Grippotyphosa & $8(72.7)$ & & $1(9.1)$ & $1(9.1)$ & $1(9.1)$ & & $\mathbf{1 1}(16.9)$ \\
\hline \multicolumn{1}{|c|}{ Total } & $\mathbf{4 4}(\mathbf{6 7 . 7})$ & $\mathbf{3 ( 4 . 6 )}$ & $\mathbf{6}(\mathbf{9 . 2})$ & $\mathbf{7 ( 1 0 . 7 )}$ & $\mathbf{4 ( 6 . 2 )}$ & $\mathbf{1 ( 1 . 5 )}$ & $\mathbf{6 5}$ \\
\hline
\end{tabular}

Table.3 Seroprevalence of leptospira infection based on MAT

\begin{tabular}{|c|c|c|}
\hline Districts & Samples tested & Positive \\
\hline Vlorë & 51 & $6(11.8 \%)$ \\
\hline Lezhë & 99 & $11(11.1 \%)$ \\
\hline Durrës & 271 & $34(12.6 \%)$ \\
\hline Shodër & 129 & $14(10.9 \%)$ \\
\hline Total & 550 & $65(11.9 \%)$ \\
\hline
\end{tabular}

Fig.1 Percentage of farms positive for leptospirosis infection in different districts of Albania

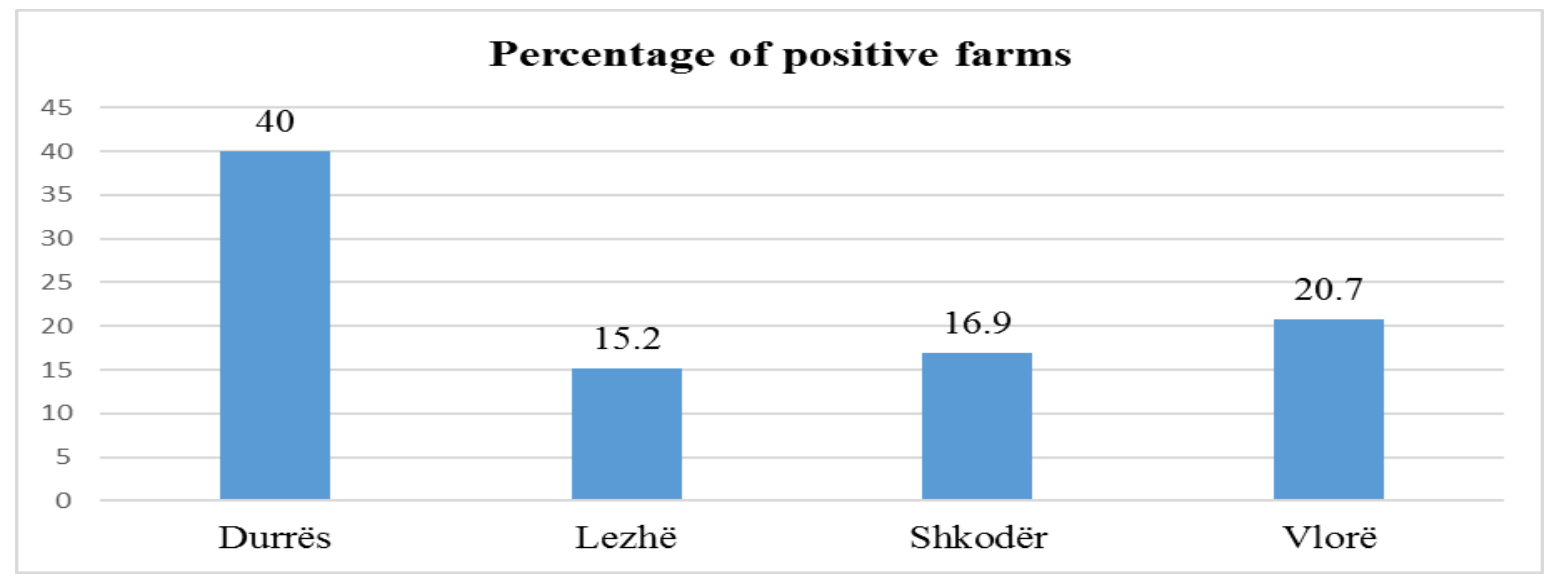


Fig.2 Different leptospira serovars detected by MAT in different districts of Albania

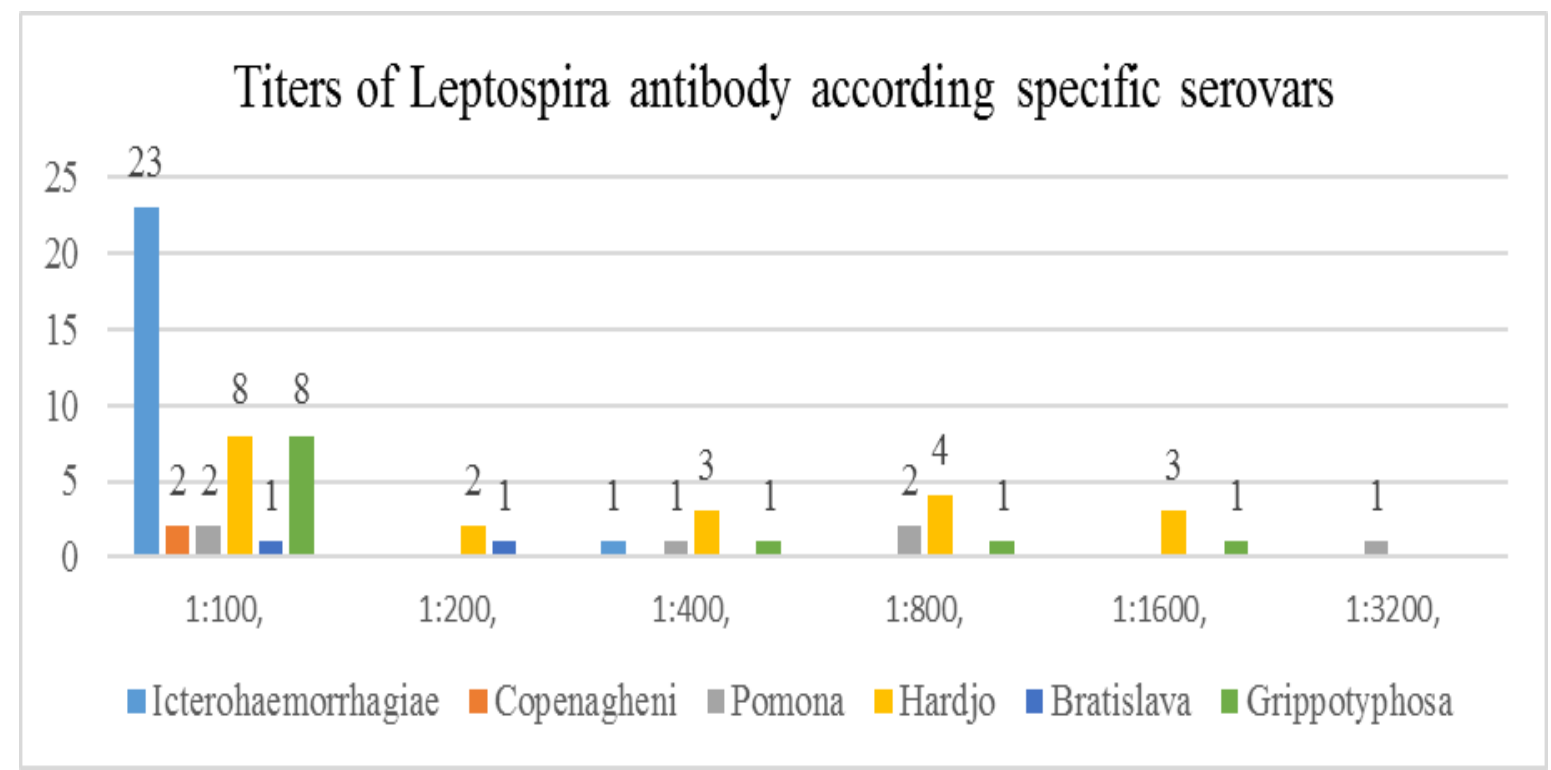

The antibody titers for L. hardjo, for which cattle are the main reservoirs of infection, was as follow: $40 \%$ of samples belong to titer $1: 100,10 \%$ at level $1: 200,15 \%$ were at level 1:400, 20\% at level 1:800 and 15\% at level 1:1600 (Table 2).

The antibody titers for L.bradislava were at level 1:100 and 1:200 respectively. The antibody titers for $L$. Grippotyphosa range from $1: 100(72.7 \%)$ to $1: 1600 \quad(27.3 \%)$ (Table 2). Antibodies against one or more serovars were detected in $65(11.9 \%)$ cattle (Table 1).

Antibodies against two serovars were found in five $(7.7 \%)$ sera samples. Mix infection was evident in Durrës in 3 samples and coinfection of L. ichterohaemorhagiae, and L. hardjo, L. grippotyphosa and $L$. copenhageni respectively was serologically identified.

The presence of coinfection was found in Lezhë, and 2 samples shown positive results for serovars Ichterohaemorhagiae and Pomona and other for Ichterohaemorhagiae and Grippotyphosa, respectively.
The presence of infection and dominant titre of 1:100 reveal that leptospiral infection in cattle in Shkodra, Lezhë, Durrës and Vlorë is endemic and occurs mostly in subclinical form, however our study show that acute infection is active in some farms.

\section{References}

Ajay, R., Bharti, Jarlath, E., Nally, Jessica, N., Ricaldi, Michael, A., Matthias, Monica, M., Diaz, Michael, A., Lovett, Paul, N., Levett, Robert, H., Gilman, Michael, R., Willig, Eduardo Gotuzzo, Joseph, M., Vinetz. 2003. Leptospirosis: a zoonotic disease of global importance. The Lancet Infect. Dis., Volume 3, Issue 12, Pages 757771.

Cumberland, P., Everard, C.O., Levett, P.N. 1999. Assessment of the efficacy of an IgM-ELISA and microscopic agglutination test (MAT) in the diagnosis of acute leptospirosis. Am. J. Trop. Med. Hyg., Vol 61(5): 731-4.

Garvey, P., J. Connell, D. O'flanagan and P. McKeown. 2014. Leptospirosis in Ireland: annual incidence and 
exposures associated with infection, Epidemiol. Infect., Volume 142, Issue 04, pp 847 - 855.

Lilenbaum, W. and G. Martins. 2014. Leptospirosis in Cattle: A Challenging Scenario for the Understanding of the Epidemiology. Transbound Emerg. Dis., 61 Suppl 1: 63-8. doi: 10.1111/tbed.12233.

Miller, D.A., Wilson, M.A. and Beran, G.W. 1991. Relationship between prevalence of Leptospira interrogans in cattle, and regional climatic, and seasonal factors. Am. J. Vet. Res., 52: 1761-1768.

Mughini-Gras, L., L. Bonfanti, A. Natale, A. Comin, A. Ferronato, E. La Greca, T. Patregnani, L. Lucchese and S. Marangon. 2014. Application of an integrated outbreak management plan for the control of leptospirosis in dairy cattle herds. Epidemiol. Infect., Volume 142, Issue 06, pp 1172-1181.
OIE, 2014. Leptospirosis. Manual of Diagnostic Tests and Vaccines for Terrestrial Animals. OIE 2.1.9. 7th e

Prescott, J.F., R.B. Miller, V.M. Nicholson, S.W. Martin, T. Lesnick. 1988. Seroprevalence and association with abortion of leptospirosis in cattle in Ontario. Can. J. Vet. Res., 52(2): 210-215.

Rebeca Plank, Deborah Dean. 2000. Overview of the epidemiology, microbiology, and pathogenesis of Leptospira spp. in humans. Microbes and Infection, Volume 2, Issue 10, August 2000, Pages 12651276.

Wynwood, S.J., M.A., Burns, G.C., Graham, S.L., Weier, D.B., McKay and S.B. Craig. 2016. Serological diagnosis of Leptospirosis in bovine serum samples using a microsphere immunoassay. Vet. Rec. Open, 3(1): e000148.

\section{How to cite this article:}

Luljeta Alla, Rushdi Keçi and Xhelil Koleci. 2016. Serologic Study on Leptospirosis Infection in Cattle in Main Albanian Coastline Districts. Int.J.Curr.Microbiol.App.Sci. 5(10): 10-15. doi: http://dx.doi.org/10.20546/ijcmas.2016.510.002 